\title{
European Identities and Transcultural Exchange. Studies in Art History
}

This book is the first volume of an international scholarly series that aims to investigate the shaping and reshaping of European identities, taking into account the migration of knowledge, ideas, ways of life, and artistic expression and technique. This dynamic approach is based on the concept of mutual cultural exchange; it includes the interactions between local traditions and imported models, between artistic methods and crafts, and the complex processes of assimilation and resistance. The series will probe the political, social, religious and cultural backgrounds of works of art and the artistic self-representation of rulers, governments and religious institutions. Such an interdisciplinary perspective is intended to take hold of the intellectual and artistic energies stemming from cultural affinities and incompatibilities. Last but not least, the series aims to offer accessible exemplary and methodically sound interpretations of artistic forms and creative processes.

Founded on a PhD thesis supervised by the École Pratique des Hautes Études, PSL, Paris, and the University of Verona, the present volume, Bernard Palissy. Artisan des réformes entre art, science et foi, by Juliette Ferdinand engages immediately with this issue. It deals with the French Huguenot potter, hydraulic engineer and naturalist Bernard Palissy (I5IO-I589) and provides a new interpretation of his "rustic ware" in the context of the Protestant Reformation, divided by the main fields of his activity: artistic practice; natural sciences; and religious belief. The final part of the volume provides a catalogue of his more significant works, mainly pottery decorated with images of fish, crustaceans, reptiles, frogs and plants, inspired by the marshes of his native Saintonge and characterized by coloured lead glazes. The book demonstrates how these creations reflect the contemporary debates pursued by Reformed theologians around the representation of the sacred and the functions of art. But it also depicts the fundamental role of Palissy's defence of craftsmanship and empirical knowledge vis-à-vis the theoretical culture of the universities and academies of the time.

Palissy's writings clearly show the influence of the Swiss missionaries of Jean Calvin preaching in the Saintonge; they also reveal affinities with Erasmus' thought, while the iconography of his ceramics is close to that of German artists from 
Nuremberg. His whole output is a distinctive example of the migration and blending of artistic trends and ideas from France, Italy, Switzerland and Northern Europe. Palissy's European outlook produced an original oeuvre that can be considered a translation of religious concepts into entirely new forms of artistic expression.

Although the artist never hid his Protestant beliefs, powerful patrons - such as the Queen Mother Catherine de' Medici and Anne de Montmorency, the Constable of France - gave him protection and commissioned him to create gardens and grottoes. Juliette Ferdinand deepens our understanding of Palissy's rustiques figulines, which the artist himself in his Recepte véritable described as expressions of a return to nature, a common topic in this period. The relationship between his theory and practice becomes a key to better understanding the artist's creative processes. The identification of his sources and reflection on their spiritual significance, based on a new interpretation of biblical citations, brings to light both Palissy's religious ideals and his personal aesthetics. While his strong personality remained a source of fascination for later periods, his rustic pottery catered to the $16^{\text {th }}$-century culture of collecting curiosities. The discovery of a close relationship between art, technical expertise, spirituality and science in Palissy's work leads to a new interpretation of his oeuvre, one stressing the interaction between the spiritual exigencies of a reformed artist and his vision of a reformed French society.

On account of her close reading of the interconnections between art, science and written theory in the time of Palissy, Juliette Ferdinand's work can be considered a substantial contribution to the study of transcultural exchange and the renewal of typologies and artistic features in the Early Modern period.

Sabine Frommel and Eckhard Leuschner

February 2019 